\title{
Partition of five aroma compounds between air and skim milk, anhydrous milk fat or full-fat cream
}

\author{
Anne MEYNIER*, Aurélie GARILLON, Laurent LETHUAUT, Claude GENOT
}

INRA, LEIMA, BP 71627, 44316 Nantes Cedex 3, France

(Received 17 September 2002; accepted 11 December 2002)

\begin{abstract}
The present study deals with the physicochemical interactions between aroma compounds and various dairy media used as models of complex food matrices, as well as the consequences of the interactions on aroma partitioning between the air and matrix. Five aroma compounds were investigated: amyl and isoamyl acetate, ethyl pentanoate, hexanal and t-2-hexenal. Skim milk, anhydrous milk fat and full-fat cream were chosen as dairy media, while water was used as a reference medium. Apparent partition coefficients of the five aromas were determined between the air and media between 30 and $80{ }^{\circ} \mathrm{C}$ by static headspace-gas chromatography. Partition coefficients over full-fat cream were also calculated from partition coefficients over skim milk and anhydrous milk fat. Compared with water, a significant retention of t-2-hexenal was observed in skim milk (nearly $90 \%$ whatever the temperature), whereas the retention of the other aromas varied from $6 \%$ for isoamyl acetate to $40 \%$ for hexanal in skim milk. Hydrophobic interactions were responsible for the retention of esters, whereas covalent binding of t-2-hexenal by dairy proteins was probably involved. The volatility of the 5 aromas was drastically reduced over anhydrous milk fat, because of their hydrophobic nature $(\log P>1)$. There were discrepancies between calculated and measured partition coefficients over full-fat cream, which depended on aroma compounds and temperature. Measured and calculated ethyl pentanoate retentions were similar whatever the temperature. For isoamyl acetate, hexanal and, to a lesser extent, t-2-hexenal, aroma retention was greater than expected. The reverse phenomenon was observed with amyl acetate. The so-called "enthalpy of affinity" was calculated from the variation of the partition coefficient with temperature. This parameter allowed an overview of the relative importance of aroma compounds-matrices interactions.
\end{abstract}

\section{Anhydrous milk fat / aroma compounds / cream / skim milk / partition coefficient}

Résumé - Partage de cinq composés d'arôme entre l'air et différentes matrices laitières : lait écrémé, matière grasse laitière anhydre, et crème liquide entière. Les coefficients de partage de composés d'arôme entre l'air et différents milieux laitiers ont été mesurés pour évaluer les interactions entre les constituants de matrices alimentaires complexes et les arômes. Cinq composés d'arôme ont été considérés : les acétates d'amyle et d'isoamyle, le pentanoate d'éthyle, l'hexanal et le t-2-hexénal. Le lait écrémé, la crème liquide entière et la matière grasse laitière anhydre ont été aromatisés avec chacun de ces arômes. Des mesures ont été effectuées au-dessus de l'eau, prise comme milieu de référence. Les coefficients de partage ont été déterminés entre 30 et $80^{\circ} \mathrm{C}$ par analyse de l'espace de tête en mode statique. Les résultats indiquent une forte rétention du t-2hexénal dans le lait écrémé (env. $90 \%$ ). La rétention des autres arômes varie de $6 \%$ pour l'acétate

* Correspondence and reprints

Tel.: (33) 02-40-67-52-45; fax: (33) 02-40-67-50-84; e-mail: meynier@nantes.inra.fr 
d'isoamyle à $40 \%$ pour l'hexanal. Cette rétention est sans doute liée à des interactions hydrophobes entre les arômes et les protéines du lait. Cependant dans le cas du t-2-hexénal, des liaisons covalentes avec les protéines interviennent probablement. Au-dessus de la matière grasse laitière, la volatilité des cinq arômes est très fortement réduite. Ce résultat est à relier au caractère hydrophobe des composés $(\log P>1)$. À l'exception du pentanoate d'éthyle, les coefficients de partage mesurés et calculés divergent avec une amplitude variable selon la température. L'acétate d'isoamyle, l'hexanal et dans une moindre mesure le t-2-hexénal sont plus retenus par la crème liquide que prévu par le calcul. Le phénomène inverse est observé pour l'acétate d'amyle. Les enthalpies de vaporisation des cinq arômes au-dessus des différents milieux ont été calculées à partir de l'étude de la variation des coefficients de partage en fonction de la température. Cette grandeur renseigne sur l'importance relative des interactions arôme-matrice.

Matière grasse laitière / arôme / crème / lait écrémé / coefficient de partage

\section{INTRODUCTION}

Sensory quality of foods, and in particular their flavour, are major determinants of their acceptability. Perceived flavour is the consequence of the activation of olfactory receptors due to the transport of aroma compounds through olfactory epithelium $[15,18,29]$. These compounds should be previously released from the food and into the mouth and nose of the consumer. Thus, the perceived intensity of flavour not only depends on the aroma compounds involved and their concentrations in the food, but also on their release into the mouth and nose [30]. This release depends first on the partition coefficients of the aroma, and second on the rate at which the aroma transfers from one environment to another [17, 21]. In fact, these parameters are related to physicochemical properties of both the aroma and the food matrix. They depend on temperature, food composition and structure, viscosity of the different phases, molecular interactions of the aroma with other molecules (e.g. proteins, lipids and carbohydrates) and on reversible and non-reversible bindings. Therefore, knowledge of binding behaviour of aromas within foods and of their rates of partitioning between the different phases is of great interest in the flavouring of foods, because they determine retention of flavours during processing and storage [17] and the selective release of specific compounds during mastication.
Many studies have been carried out using simple systems composed of water [3], protein solutions [14, 18, 25], or lipids $[2,16]$. Nevertheless, most food products are multi-component materials, often containing both lipids and aqueous phases. Few works have reported on the volatility of aroma compounds over complex media $[5,7,20,26]$. Among foods, fermented, gelified, renneted milks and fresh dairy products represent a significant part of the European's diet, with an average of $17.8 \mathrm{~kg} /$ year [6]. The objective of this work was to investigate the partition behaviour of some aroma compounds (3 esters and 2 aldehydes) between air and several dairy media: skim milk, anhydrous milk fat and full-fat cream. The measured partition coefficients over full-fat cream and those obtained by calculation [2] were compared to evaluate the effect of emulsification. Finally, the effect of temperature was studied to assess the consequence of incorporation of the aroma before thermal treatment or in hot dairy formulations.

\section{MATERIALS AND METHODS}

\subsection{Chemical compounds}

Amyl acetate, ethyl pentanoate, hexanal and t-2-hexenal, were supplied by Aldrich (Saint-Quentin-Falavier, France). Their purities were greater than $98 \%$. Isoamyl acetate was a gift from IFF (Longvic, 
Table I. Physicochemical and thermodynamic characteristics of the five aroma compounds.

\begin{tabular}{|c|c|c|c|c|c|c|c|c|}
\hline Compound & Structure & MW* & $\begin{array}{l}\mathrm{BP} * \\
\left({ }^{\circ} \mathrm{C}\right)\end{array}$ & $\begin{array}{c}\text { P sat* } \\
(\mathrm{mm} \mathrm{Hg})\end{array}$ & $\begin{array}{c}\mathrm{S}^{*} \\
\left(\mathrm{~g} \cdot \mathrm{L}^{-1}\right)\end{array}$ & $\log \mathrm{P}^{*}$ & $\begin{array}{l}\text { Henry's constant* } \\
\left(\mathrm{Atm} \cdot \mathrm{m}^{3} \cdot \mathrm{mol}^{-1}\right)\end{array}$ & $\begin{array}{c}\gamma \\
\text { calculated (1) }\end{array}$ \\
\hline Isoamyl acetate & & 130 & 142 & 5.6 & 2.0 & 2.26 & $5.87 \times 10^{-4}$ & 3673 \\
\hline Amyl acetate & & 130 & 149 & 3.5 & 1.7 & 2.3 & $3.88 \times 10^{-4}$ & 3664 \\
\hline Ethyl pentanoate & & 130 & 145 & 4.8 & 2.2 & 2.34 & $3.72 \times 10^{-4}$ & 5345 \\
\hline Hexanal & & 100 & 131 & 11.3 & 5.6 & 1.78 & $2.13 \times 10^{-4}$ & 82 \\
\hline t-2-hexenal & & 98 & 146 & 6.6 & 5.3 & 1.58 & $4.89 \times 10^{-5}$ & 173 \\
\hline
\end{tabular}

* http://esc-plaza.syrres.com/interkow/physdemo.htm

(1) calculated according UNIFAC.

All data were collected at $25^{\circ} \mathrm{C}(298 \mathrm{~K}) \mathrm{MW}$ : molecular weight; BP: boiling point; Psat: saturated vapour pressure; $\mathrm{S}$ : solubility in water; $\log \mathrm{P}$ : $\log$ partition coefficient between water and octanol; $\gamma$ : activity coefficient.

Table II. Ranges of aroma concentrations $\left(\mathrm{mg} \cdot \mathrm{L}^{-1}\right)$ in the different media for partition coefficient determination.

\begin{tabular}{lcccc}
\hline & Water & Skim milk & Full-fat cream & Anhydrous milk fat \\
\hline Isoamyl acetate & $2-200$ & $2-200$ & $65-6500$ & $200-20000$ \\
Amyl acetate & $2-200$ & $2-200$ & $120-1200$ & $100-8000$ \\
Ethyl pentanoate & $6-600$ & $5-500$ & $50-5000$ & $150-15000$ \\
Hexanal & $1-100$ & $2-200$ & $20-2000$ & $40-4000$ \\
t-2-hexenal & $3-300$ & $100-5800$ & $20-2000$ & $200-20000$ \\
\hline
\end{tabular}

France). The physicochemical and thermodynamic constants of the studied aromas are given in Table I. Ultrapure water was prepared with a Millipore system. "Lactel" skim milk UHT (sm) and "Elle \& Vire" full-fat cream ( $30 \%$ milk fat, ffc) were purchased from a local supermarket. France Beurre (Quimper, France) supplied anhydrous milk fat (amf), which exhibited a melting point of $32-35{ }^{\circ} \mathrm{C}$. Prior to flavouring, anhydrous milk fat was melted at $60{ }^{\circ} \mathrm{C}$ (more than $20^{\circ} \mathrm{C}$ above the melting point) for $1 \mathrm{~h}$ to erase the thermal history of the fat and then maintained at $40{ }^{\circ} \mathrm{C}$ before flavouring and analyses.

\subsection{Sample preparation}

Stock solutions of aromas were prepared by accurately weighing each aroma into each studied media at room temperature. Their concentrations were under the maximum solubility of the aroma in the chosen medium. Five concentrations of the aroma in each medium were prepared. Solutions were equilibrated for $1 \mathrm{~h}$ at room temperature in closed flasks under mild stirring. Concentration ranges for each aroma are given in Table II.

\subsection{Determination of partition coefficients}

Partition coefficients were defined as the ratio of the concentration of each aroma in the gaseous phase $\left(\mathrm{ng} \cdot \mathrm{mL}^{-1}\right)$ to its concentration in the liquid phase (ng. $\mathrm{mL}^{-1}$ ), which was calculated after an accurate weighing. The former concentration 
Table III. Measured air-medium partition coefficients $\left(\times 10^{3}\right)$ of aroma compounds at $30{ }^{\circ} \mathrm{C}$.

\begin{tabular}{lccccc}
\hline Media & Isoamyl acetate & Amyl acetate & $\begin{array}{c}\text { Ethyl } \\
\text { pentanoate }\end{array}$ & Hexanal & t-2-hexenal \\
\hline Water & $\mathbf{4 . 5} \pm 0.6$ & $\mathbf{3 . 0} \pm 0.4$ & $\mathbf{2 . 8} \pm 0.1$ & $\mathbf{2 . 5} \pm 0.1$ & $\mathbf{0 . 4 4} \pm 0.07$ \\
Skim milk & $\mathbf{4 . 2} \pm 0.5$ & $\mathbf{2 . 5} \pm 0.2$ & $\mathbf{2 . 1} \pm 0.3$ & $\mathbf{1 . 8} \pm 0.2$ & $\mathbf{0 . 0 6 4} \pm 0.027$ \\
$\begin{array}{l}\text { Anhydrous } \\
\text { milk fat }\end{array}$ & $\mathbf{0 . 0 5 7} \pm 0.003$ & $\mathbf{0 . 0 1 4} \pm 0.002$ & $\mathbf{0 . 0 1 3} \pm 0.002$ & $\mathbf{0 . 0 8 2} \pm 0.006$ & $\mathbf{0 . 0 1 0} \pm 0.001$ \\
Full-fat cream & $\mathbf{0 . 1 4} \pm 0.02$ & $\mathbf{0 . 0 6 0} \pm 0.003$ & $\mathbf{0 . 0 3 7} \pm 0.004$ & $\mathbf{0 . 1 6} \pm 0.03$ & $\mathbf{0 . 0 1 8} \pm 0.005$ \\
\hline
\end{tabular}

Values are mean of 10 measurements (5 concentrations in duplicate); (bold: mean, plain: standard deviation).

was measured by headspace analyses, which were carried out with a Perkin-Elmer HS 40XL automatic sampler (Norwalk, USA) paired with a HP 5890 gas chromatograph (Böblingen, Germany). Three grams of each sample were introduced into 22.4-mL headspace vials. The vials were sealed immediately with PTFE-silicon caps. Duplicates were prepared for each solution. Then, the vials were equilibrated at the appropriate temperature from 30 to $80{ }^{\circ} \mathrm{C}$ for $30 \mathrm{~min}$, except for skim milk, for which 60 min equilibrium was required. These equilibrium times were determined experimentally before the analyses. The pressurisation time of the headspace samples was set at $2.0 \mathrm{~min}$ and injected volume ranged from to $75 \mu \mathrm{L}$ to $400 \mu \mathrm{L}$ according to the temperature and detector sensitivity and linearity. Gaseous headspace samples were injected using the splitless mode (inlet temperature: $250{ }^{\circ} \mathrm{C}$ ). The purge was switched off during the first $1.5 \mathrm{~min}$ and then switched on. An initial temperature of $40{ }^{\circ} \mathrm{C}$ was used for $1 \mathrm{~min}$, followed by a rate of $7{ }^{\circ} \mathrm{C} \cdot \mathrm{min}^{-1}$ to $140{ }^{\circ} \mathrm{C}$. Compounds were separated on a capillary column (DB $22530 \mathrm{~m}$ length, $0.32 \mathrm{~mm}$ id. and $0.25 \mu \mathrm{m}$ film thickness; J\&W Scientific, Chromoptic, Auxerre, France; helium carrier gas = $\left.1.9 \mathrm{~mL} \cdot \mathrm{min}^{-1}\right)$. The detector temperature was set at $250{ }^{\circ} \mathrm{C}$. The flame ionisation detector (FID) was calibrated by manual injections of aroma compounds in cyclohexane. Four concentrations of each aroma solution were analysed in duplicate by 3 different operators. The variation coefficients of response factor were less than $5 \%$ between operators.

\subsection{Statistical Analysis}

Variance analysis (ANOVA) was used to determine the effect of media and temperature on partition coefficients. If significant effects were found, least significant difference (LSD) tests were performed. The significance level was $P<0.05$ throughout the study. The statistical analyses were performed with Statgraphics Plus 3.0.

\section{RESULTS}

Table III summarises partition coefficients obtained over the different media at $30{ }^{\circ} \mathrm{C}$. Whatever the temperature, the media, and the aroma compounds, headspace concentration was a linear function of liquid concentration over the studied range.

\subsection{Partitions of aroma compounds between fat-free media and air}

Whatever the temperature, the volatility of the aromas over water and skim milk increased in the following order: $\mathrm{t}$-2-hexenal $<$ ethyl pentanoate $\sim$ hexanal $<$ amyl acetate $<$ isoamyl acetate (Figs. 1 and 2, Tab. III). Measured partition coefficients over water ranged from $4.4 \times 10^{-4}$ for $\mathrm{t}$-2-hexenal 


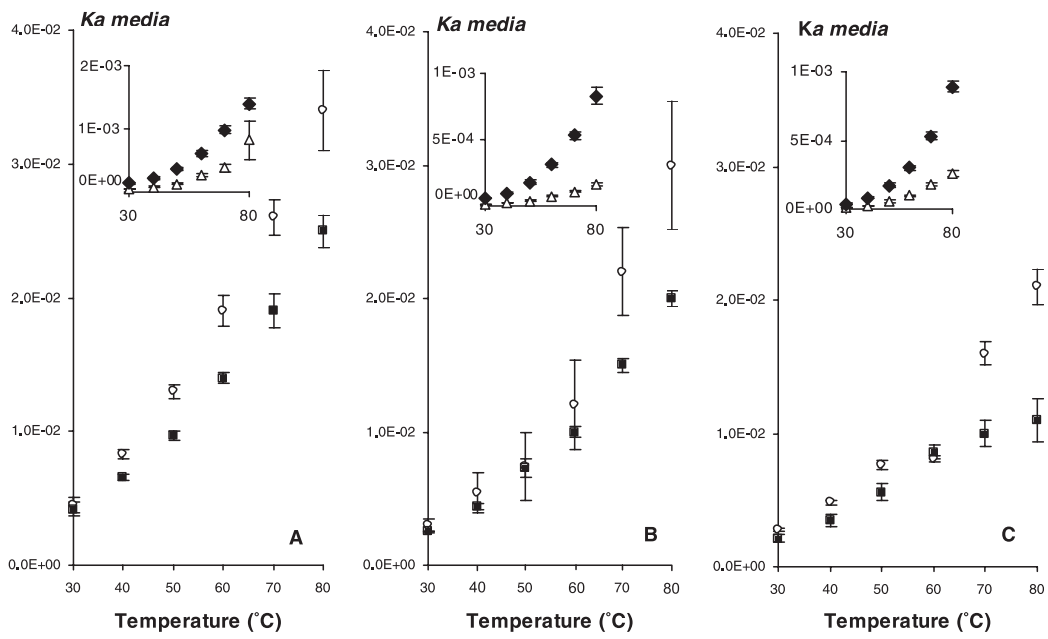

Figure 1. Comparison of partition behaviour of esters over water and dairy media: (A) isoamyl acetate; (B) amyl acetate; (C) ethyl pentanoate. Main graph: water and milk, cut-in graph: full-fat cream and anhydrous milk fat. $(O)$ water, $(\square)$ skim milk, $(\triangle)$ milk fat, $(\bullet)$ full-fat cream.
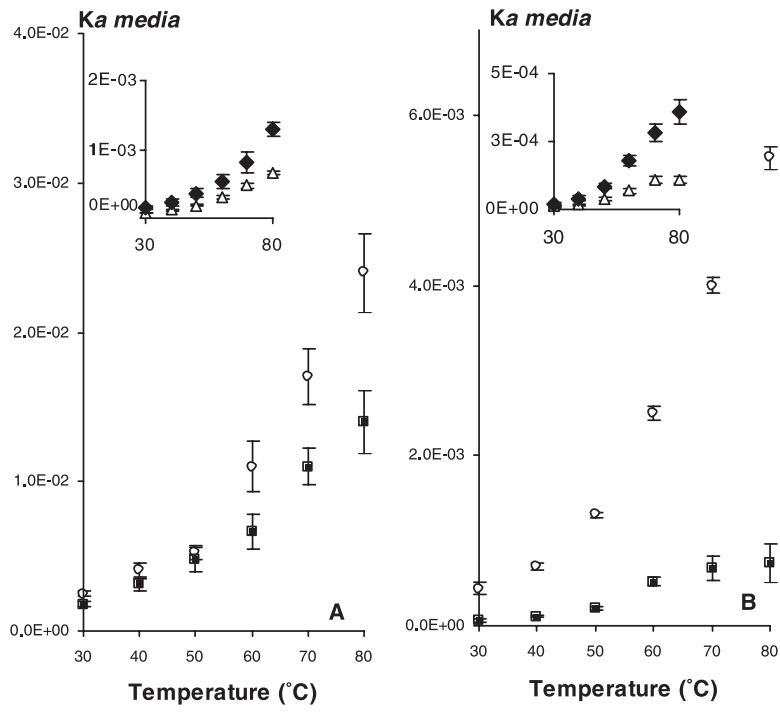

Figure 2. Comparison of partition behaviour of aldehydes over water and dairy media: (A) hexanal; (B) t-2-hexenal. Main graph: water and milk, cut-in graph: full-fat cream and anhydrous milk fat. (O) water, (ロ) skim milk, $(\triangle)$ milk fat, $(\bullet)$ full-fat cream.

at $30^{\circ} \mathrm{C}$ to $3.4 \times 10^{-2}$ for isoamyl acetate at $80^{\circ} \mathrm{C}$. For comparison, air-water partition coefficients of $1.8 \times 10^{-2}$ and $3.8 \times 10^{-3}$ at $30{ }^{\circ} \mathrm{C}$ for hexanal and $\mathrm{t}$-2-hexenal were previously measured by Hall and Anderson [16] against $2.5 \times 10^{-3}$ and $0.44 \times 10^{-3}$ in this study. The discrepancy between the results can be attributed to the use of 
ammonium sulphate in the latter study. This compound has a salting-out effect, and increases the volatility of aroma compounds, increasing their partition coefficients. Another explanation of these differences is the sampling method of the headspace as well as the injection mode.

The air-medium partition coefficients of the 5 aroma compounds increased with temperature. Generally, they were lower between air and skim milk than between air and water. As the lipid content of skim milk was less than $0.3 \%$, the retention of aromas in milk cannot only be attributed to lipids. Isoamyl acetate (Fig. 1A) exhibited a significantly lower partition coefficient over skim milk than over water at all temperatures except $30^{\circ} \mathrm{C}$. As compared with water, retention of isoamyl acetate in skim milk varied from $20 \%$ at $40{ }^{\circ} \mathrm{C}$ to $26 \%$ at $80^{\circ} \mathrm{C}$. For amyl acetate (Fig. 1B), retention became significant above $70{ }^{\circ} \mathrm{C}(\sim 30 \%)$. For ethyl pentanoate (Fig. 1C), the partition coefficients between air and skim milk were significantly lower than those observed between air and water from 30 to $80^{\circ} \mathrm{C}$. Retention ranged from $25 \%$ at $30{ }^{\circ} \mathrm{C}$ to $48 \%$ at $80{ }^{\circ} \mathrm{C}$. The partition coefficient over skim milk tended to level off between $70{ }^{\circ} \mathrm{C}$ and $80{ }^{\circ} \mathrm{C}$ whereas it increased exponentially for other esters (see the section on the effect of temperature). As esters, hexanal and t-2-hexenal exhibited different partition behaviour over skim milk than over water (Fig. 2). The partition coefficients of hexanal (Fig. 2A) over skim milk and water became significantly different above $60{ }^{\circ} \mathrm{C}$, and the retention reached $42 \%$ at $80{ }^{\circ} \mathrm{C}$. Concerning t-2-hexenal (Fig. 2B), the accurate quantification of this compound in the gaseous phase over skim milk needed much higher concentration in the liquid phase: 5.8 to $0.2 \mathrm{~g} \cdot \mathrm{L}^{-1}$ in milk compared with 0.3 to $3 \times 10^{-3} \mathrm{~g} \cdot \mathrm{L}^{-1}$ in water. In presence of such amounts of $\mathrm{t}$-2-hexenal, the skim milk turned in brownish in colour, even when the solution was kept for a few hours at $4{ }^{\circ} \mathrm{C}$. The partition coefficient over skim milk was approximately $85 \%$ lower than over water whatever the temperature. As covalent bindings between $\mathrm{t}$-2-hexenal and dairy proteins are probably involved [1], the partition coefficient must be considered as "apparent".

\subsection{Partition of aroma compounds between fat-containing media and air}

The partition coefficients between anhydrous milk fat (amf) and air at $30{ }^{\circ} \mathrm{C}$ are presented in Table III. When compared with other media, the partition coefficients decreased drastically when aromas were added to milk fat. They ranged from $1 \times 10^{-5}$ to $8.2 \times 10^{-5}$ at $30^{\circ} \mathrm{C}$. The volatility increased in the following order: t-2-hexenal $\sim$ ethyl pentanoate $\sim$ amyl acetate $<$ isoamyl acetate $<$ hexanal.

The partition coefficients between air and full-fat cream (ffc) measured at $30{ }^{\circ} \mathrm{C}$ are also presented in Table III. When compared with water and skim milk, the partition coefficients of all aromas decreased sharply and ranged from $1.8 \times 10^{-5}$ to $1.6 \times 10^{-4}$ at $30^{\circ} \mathrm{C}$. The volatility of aroma compounds increased in the following order: t-2-hexenal $<<$ ethyl pentanoate $<$ amyl acetate $<<$ isoamyl acetate $\sim$ hexanal. At $30^{\circ} \mathrm{C}$, the partition coefficients were approximately two-fold lower for anhydrous milk fat ( $100 \%$ fat) than for full-fat cream (30\% fat), whereas they were approximately a hundred-fold lower in anhydrous milk fat than in water.

\subsection{Variation of partition coefficients with temperature: enthalpy of affinity}

As shown in Figures 1 to 4, the relationship between the temperature and the partition coefficients is not a straight line, but a linear relationship can be found when the logarithm of partition coefficient is plotted as a function of $1 / \mathrm{T}(\mathrm{K})$ (data not shown). This behaviour can be related to the Clausius-Clapeyron equation:

$$
\frac{\mathrm{d} \ln p}{\mathrm{dT}}=\frac{\Delta \mathrm{H} v a p}{\mathrm{RT}^{2}}
$$



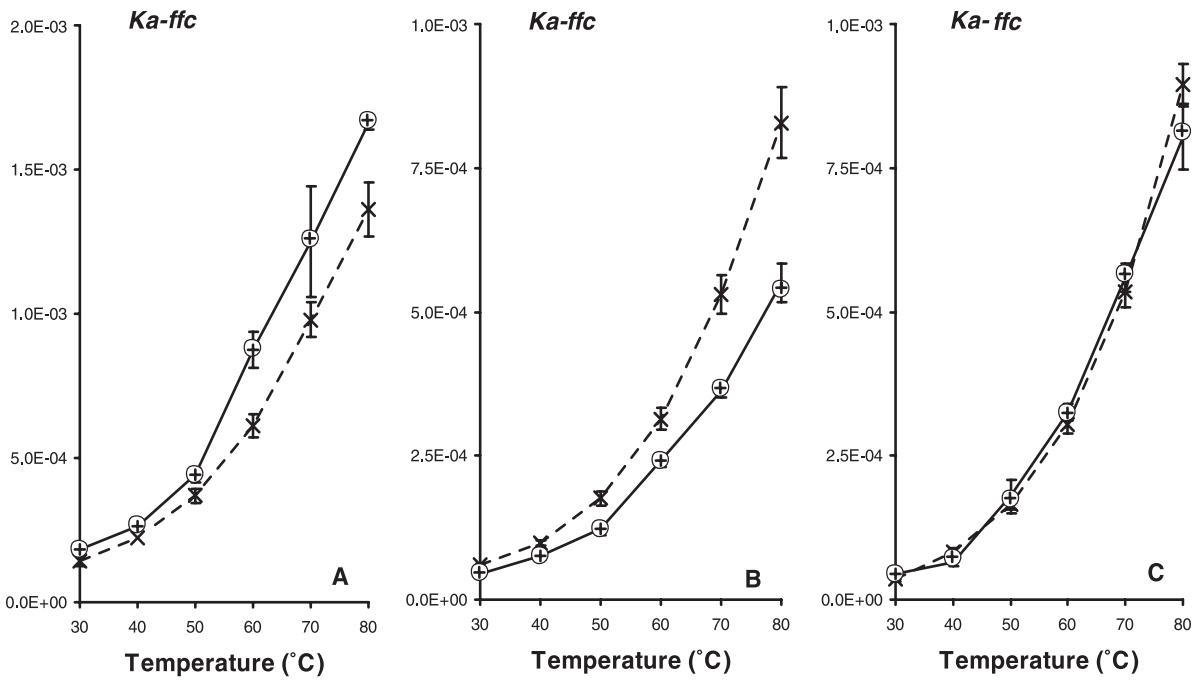

Figure 3. Comparison of measured and calculated partition coefficients of esters between air and full-fat cream: (A) isoamyl acetate; (B) amyl acetate; (C) ethyl pentanoate. ( $\times$ ) measured dotted line, (O) calculated with water as continuous phase, $(+)$ calculated with skim milk as continuous phase, continuous line.
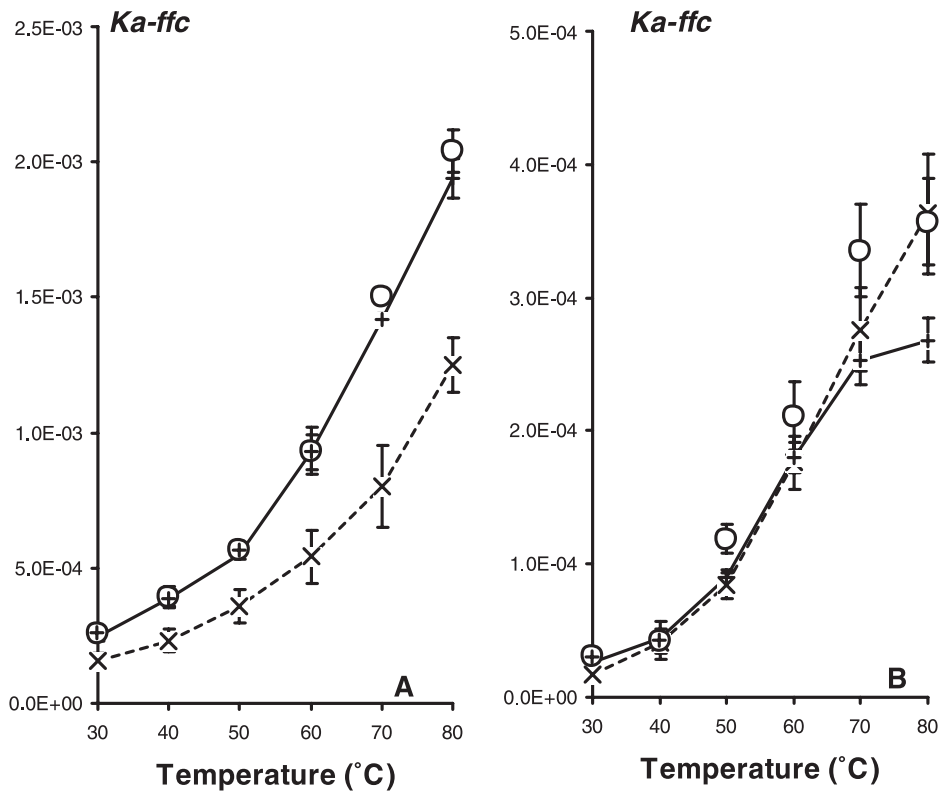

Figure 4. Comparison of measured and calculated partition coefficients of aldehydes between air and full-fat cream. (A) hexanal; (B) t-2-hexenal. $(x)$ measured, dotted line, $(O)$ calculated with water as continuous phase, $(+)$ calculated with skim milk as continuous phase, continuous line. 
Table IV. Enthalpies of affinity of the five aroma compounds in water and various dairy matrices.

\begin{tabular}{lccccc}
\hline$\Delta \mathrm{H}\left(\mathrm{kJ} \cdot \mathrm{mol}^{-1}\right)$ & Isoamyl acetate & Amyl acetate & Ethyl pentanoate & Hexanal & t-2-hexenal \\
\hline Pure compound & $44.0^{(\mathrm{a})}$ & $41.9^{\text {(a) }}$ & $46.0^{(\mathrm{b})}$ & $45.3^{\text {(a) }}$ & $44.8^{\text {(c) }}$ \\
Water & $\mathbf{3 5 . 7} \pm 1.6$ & $\mathbf{4 1 . 2} \pm 1.7$ & $\mathbf{4 0 . 3}^{(1)} 1.3^{(1)}$ & $\mathbf{4 0 . 4} \pm 1.7$ & $\mathbf{4 7 . 2} \pm 1.8$ \\
Skim milk & $\mathbf{3 2 . 0} \pm 0.7$ & $\mathbf{3 6 . 5} \pm 1.7$ & $\mathbf{3 9 . 7} \pm 0.4^{(2)}$ & $\mathbf{3 6 . 0} \pm 1.0$ & $\mathbf{4 9 . 2} \pm 4.5^{(2)}$ \\
Anhydrous milk & $\mathbf{4 7 . 2} \pm 3.3$ & $\mathbf{4 4 . 5} \pm 1.1$ & $\mathbf{5 5 . 6} \pm 3.3$ & $\mathbf{3 7 . 9} \pm 1.3$ & $\mathbf{4 5 . 5} \pm 3.9$ \\
fat & & & & & \\
Full-fat cream & $\mathbf{4 1 . 3} \pm 0.9$ & $\mathbf{4 7 . 7} \pm 1.0$ & $\mathbf{5 6 . 5} \pm 1.1$ & $\mathbf{3 6 . 8} \pm 1.0$ & $\mathbf{5 5 . 3} \pm 3.5$ \\
\hline
\end{tabular}

Bold: mean, plain: standard deviation. * Enthalpy of vaporisation. (a) Calculated from data in the Handbook of Chemistry and Physics from the variation of vapour pressure as a function of temperature, [31]; (b) from Ducros et al. (1980) [9]; (c) from Philippe et al. (2002) [24]; (1) calculated from 30 to $50{ }^{\circ} \mathrm{C}$;

(2) calculated from 30 to $60{ }^{\circ} \mathrm{C}$.

where $p$ refers to vapour pressure, $\Delta \mathrm{H} v a p$ refers to enthalpy of vaporisation, and $\mathrm{T}$ is the temperature expressed in Kelvin (K), R: perfect gas constant.

If we assume that $\Delta \mathrm{Hvap}$ does not depend on the temperature of the system, the Clausius-Clapeyron equation can be written in the following integrated form:

$$
\ln p=-\frac{\Delta \mathrm{H} v a p}{\mathrm{RT}}+\mathrm{C} .
$$

Vapour pressure variation as a function of temperature allowed the estimation of the enthalpy of vaporisation in the case of pure compounds [8] using equation (2). In our case, variations of partition coefficient between complex media and air as a function of temperature were studied. An equation similar to equation (2) can be consequently proposed:

$$
\ln \mathrm{K}_{\text {amedium }}=-\frac{\Delta \mathrm{H}_{\text {aff }}}{\mathrm{RT}}+\mathrm{C}^{\prime}
$$

where $\Delta \mathrm{H}_{\text {aff }}$ will refer to the so-called "enthalpy of affinity" of a given aroma for a medium, and will be calculated by plotting $\ln \mathrm{K}_{\text {amedium }}=\mathrm{f}(1 / \mathrm{T})$ as follows: $\Delta \mathrm{H}_{\text {aff }}=-($ slope $\times \mathrm{R}) ; \quad \mathrm{R}:$ perfect gas constant $=8.314 \mathrm{~J} \cdot \mathrm{mol}^{-1} ; \Delta \mathrm{H}_{\text {aff }}$ will be expressed in $\mathrm{kJ} \cdot \mathrm{mol}^{-1}$.

The partition coefficient takes into account the vapour pressure of the compound as well as the environment of the aroma (constituents of the matrix i.e. water, proteins and lipids...). In contrast, and "enthalpy of affinity" is directly linked to the attraction or repulsion forces that retain or release the aroma compounds in their environment.

The results are tabulated in Table IV. It should be first underlined that, in contrast to the partition coefficients, all data are in the same order of magnitude, varying from 32 to $57 \mathrm{~kJ} \cdot \mathrm{mol}^{-1}$. This indicates that the energy needed for the volatilisation of aroma compounds remains similar whatever their environment. However, some differences can be found according to the aroma and the medium. With the exception of t-2-hexenal and, to a lesser extent, amyl acetate, the so-called enthalpies of affinity in water were lower than the enthalpies of vaporisation of pure compounds. These findings suggest that aroma-aroma interactions were greater than aroma-water interactions. Enthalpies of affinity tended to be lower in skim milk than in water, with the exception of t-2-hexenal and, to a lesser extent, of ethyl pentanoate. The increase of enthalpy of affinity of t-2-hexenal was logical considering the strong interaction of this aroma with dairy proteins. The enthalpies of affinity of esters were higher in anhydrous milk fat than in water and skim milk. This suggests stronger interactions of esters with milk fat lipids, than with water or skim milk, which is in agreement 
with the $\log P$ values of the esters. Nevertheless, the differences between the enthalpies of affinity of the esters were by far more significant than the differences in $\log P$ values. It can be assumed that the enthalpy of affinity in lipids was not only related to the hydrophobicity of the compounds, but also to interactions of aroma compounds with the fatty chain of triglycerides, dissolving properties, etc. The enthalpies of affinity of aldehydes were similar in milk fat and in lipid-free media.

With the exception of isoamyl acetate and hexanal, the enthalpies of affinity in full-fat cream gave unexpected results as related to those observed in milk and fat. Values measured in full-fat cream were greater than or similar to those measured over milk, while we expected values intermediate between those in anhydrous milk fat and skim milk. The difference was the most obvious for t-2-hexenal. We currently have no clear explanation for this phenomenon but some influence of the emulsified structure of the full-fat cream, and/or interface, could be assumed.

\section{DISCUSSION}

\subsection{Partition over water and skim milk: effect of proteins on aroma partition}

Data related to partition of aromas between air and complex media such as skim milk are sparse. The only data that we have found using a related system gave results contrary to ours. Hence, the partition coefficient of isoamyl acetate was found to be higher over milk than over water [4], but in this work milk was heated to $90{ }^{\circ} \mathrm{C}$ for $3 \mathrm{~min}$. In agreement with our results, another study [11] shows that esters such as ethyl hexanoate are retained by dairy proteins $\left(30 \mathrm{~g} \cdot \mathrm{L}^{-1}\right)$, especially with a mixture of whey proteins and $\beta$-lactoglobulin. The extent of retention of esters in their study ranges from $6 \%$ for ethyl butanoate to $40 \%$ for ethyl hexanoate. To explain our results, data related to interactions between dairy proteins and aroma compounds have been considered. Bovine milk contains mainly caseins $\left(29.5 \mathrm{~g} \cdot \mathrm{L}^{-1}\right)$ and whey proteins such as $\beta$-lactoglobulin $\left(3.2 \mathrm{~g} \cdot \mathrm{L}^{-1}\right)$ and $\alpha$-lactalbumin $\left(1.2 \mathrm{~g} \cdot \mathrm{L}^{-1}\right)$ [27]. Many researchers have studied the binding or retention of aroma compounds by proteins [12, 14, 17, 25].

In model systems (protein concentration $30 \mathrm{~g} \cdot \mathrm{L}^{-1}, \mathrm{pH} 3$ ), it was shown that $\beta$-lactoglobulin binds many aroma compounds of different chemical classes, such as 2-alkanones and esters. Reported values of affinity constants of $\beta$-lactoglobulin with esters ranged from 366 for ethyl pentanoate [25] to 543-627 for isoamyl acetate [14]. In the latter case, the authors reported that retention of isoamyl acetate by $\beta$-lactoglobulin ranged from 1 to $16 \%$. This retention was weak as compared with values of 44 to $60 \%$ for 2-nonanone [14]. When available, affinity constants of aroma compounds for $\alpha$-lactalbumin were lower than for $\beta$-lactoglobulin [5]. Another study highlighted that the effect of protein (albumin) on the headspace concentration of isoamyl acetate was weak [10]. UHT processing caused partial, irreversible unfolding of $\beta$-lactoglobulin, which increases its surface hydrophobicity [28]. Such a phenomenon could partly explain the increase in retention we observed with temperature.

Concerning aldehydes, less data are available. At pH 6.9, the binding of heptanal to whey proteins was greater than the binding of 2-nonanone, while at $\mathrm{pH} 4.7$ the reverse occurred [23]. Moreover, the authors reported that the binding of heptanal was only partially reversible. The latter assumption was confirmed by a study on soy protein [13]. Retention of $\alpha$-monounsaturated aldehydes by soy protein was greater than that of saturated ones. For example, retention of aldehydes by $50 \mathrm{~g} \cdot \mathrm{L}^{-1}$ soy protein solution was 37 to $44 \%$ for hexanal compared with 68 to $75 \%$ for t-2-hexenal. The author suggested that retention of unsaturated aldehydes can be partly attributed to strong interactions or 
irreversible binding which was not disrupted by vacuum extraction of aromas. Studies of interactions of bovine serum albumin with 2-octenal confirm this assumption [1]. Furthermore, the authors suggest a covalent binding of 2-octenal throughout its double bond with the imidazole ring of histidine. The propensity of histidine-containing peptides to reduce the quantity of some aldehydes in the headspace has been studied $[32,33]$. These works establish that the decrease in t-2-hexenal in the headspace was greater than the decrease in hexanal.

Fewer studies have dealt with the interaction of caseins or caseinates with aroma compounds [12, 19]. Retention of ethyl esters by casein increased with the number of carbon atoms in the esters and with protein concentration [19]. The retention of ethyl hexanoate ranged from $38 \%$ in $5 \mathrm{~g} \cdot \mathrm{L}^{-1}$ caseins to $61 \%$ in $50 \mathrm{~g} \cdot \mathrm{L}^{-1}$ caseins. This observation was confirmed for other aroma compounds [12]. The authors reported that an increase of casein concentration in solution led to a decrease in aroma concentrations such as esters and aldehydes in the gaseous phase. This decrease was weak for esters below $12 \%$ casein but was significant for aldehydes from $3 \%$ protein, which is similar to the concentration of casein in skim milk. The retention of aroma compounds by caseins was attributed to the formation of a gel network at high protein concentrations. This gel reduced the volatility of aroma compounds. In skim milk, the concentration of caseins was not sufficient to allow the formation of a gel network.

To conclude, the decrease in volatility over skim milk of aroma compounds observed in our study can be partially attributed to hydrophobic interactions of esters with milk proteins such as $\beta$-lactoglobulin and caseins. For aldehydes, and especially t-2-hexenal, covalent binding with histidyl and lysyl residues of proteins are probably involved. This irreversible interaction should not be disrupted during consumption and consequently would reduce the release of $\mathrm{t}$-2-hexenal from the media.

\subsection{Partition over anhydrous milk fat: effect of fat on aroma retention}

The decrease in aroma volatility over lipids was expected as all studied aromas were lipophilic, as indicated by their $\log P$ values (see Tab. I). The more lipophilic the solute, the greater will be the decrease in volatility with lipids [22]. Nevertheless, the order observed for partition coefficients over milk lipids was not in agreement with the $\log P$ values (e.g. the closed values of $\log P$ for the aldehydes and eight-fold higher value of $\mathrm{K}_{\mathrm{a}-\mathrm{amf}}$ for hexanal compared with $\mathrm{t}$-2-hexenal).

\subsection{Partition over an emulsion: full-fat cream}

\subsubsection{Comparisons of calculated and measured partition coefficients between full-fat cream and air}

Full-fat cream is an oil-in-water emulsion containing anhydrous milk fat as the dispersed phase and the aqueous phase of milk as the continuous phase. The dispersed phase mass fraction of ffc used in this study was 0.3 . According to [2], a model can be used to evaluate the partition coefficient over a biphasic system:

$$
\mathrm{K}_{a e m}=\frac{1}{\left(\left(\Phi c p / \mathrm{K}_{a c p}\right)+\left(\Phi d p / \mathrm{K}_{a d p}\right)\right)}
$$

where $\mathrm{K}_{a e m}$ : partition coefficient between air and emulsion; $\Phi c p$ : mass fraction of continuous phase; $\Phi d p$ : mass fraction of dispersed phase; $\mathrm{K}_{a c p}$ : partition coefficient between air and continuous phase; $\mathrm{K}_{a d p}$ : partition coefficient between air and dispersed phase.

In the case of full-fat cream, we calculated the partition coefficient according to equation (4) considering firstly water as the continuous phase:

$$
\mathrm{K}_{a f f c}=\frac{1}{\left(\left(0.7 / \mathrm{K}_{a w}\right)+\left(0.3 / \mathrm{K}_{a a m f}\right)\right)}
$$


and secondly considering skim milk as the continuous phase

$$
\mathrm{K}_{a f f c}=\frac{1}{\left(\left(0.7 / \mathrm{K}_{a s m}\right)+\left(0.3 / \mathrm{K}_{a a m f}\right)\right)} \text {. }
$$

Comparisons of the experimental and calculated partition coefficients are shown in Figure 3 for the 3 esters and in Figure 4 for the 2 aldehydes. Depending on the temperature and the aroma compounds, differences appeared between the calculated and measured partition coefficients between full-fat cream and air. Thus, the partition coefficient over complex media cannot always be deduced from the partition coefficient over the constitutive phase of the media.

\subsubsection{Influence of the nature of the continuous phase on calculated partition coefficients}

As shown in Figure 3, the nature of the continuous phase had no significant effect on the calculated partition coefficient of the three esters. With the exception of $80{ }^{\circ} \mathrm{C}$ the coefficients calculated from equation (5) or equation (6) were similar for hexanal (Fig. 4A). The results were different for t-2-hexenal (Fig. 4B). The calculated values from equation (6) were significantly lower from $50{ }^{\circ} \mathrm{C}$ to $80^{\circ} \mathrm{C}$ than those calculated from equation (5). This results from differences in the partition behaviour of $\mathrm{t}$-2-hexenal in skim milk and water. Consequently, for t-2-hexenal, the nature of the continuous phase of the emulsion may be predicted to affect its partition behaviour in emulsion.

\subsubsection{Evaluation of the influence of interface layer}

Equations (4) to (6) did not take into account the presence of an interface layer. Comparison of the calculated and experimental coefficients gives an estimation of the effect of the interface on the partition coefficients. Conflicting results were observed as regards to aroma compounds and temperature (Figs. 3 and 4). Thus, isoamyl acetate and hexanal exhibited experimental coefficients significantly lower than the calculated ones above 60 and $40{ }^{\circ} \mathrm{C}$ respectively. The measured partition coefficients of t-2-hexenal were significantly lower than the calculated ones (Eq. (6) from $70{ }^{\circ} \mathrm{C}$ ). This implies that these compounds were retained in the full-fat cream to a greater extent than predicted. This retention can be attributed to the presence of an interface layer that would reduce the volatility of these compounds. On the other hand, amyl acetate exhibited a significantly greater experimental coefficient than the calculated one from $40{ }^{\circ} \mathrm{C}$, coinciding with a higher release of amyl acetate from full-fat cream than expected, i.e. the presence of an interface increased the volatility of amyl acetate. Furthermore, differences between measured and calculated values increased with temperature. Concerning ethyl pentanoate, no significant difference was noted from 30 to $80^{\circ} \mathrm{C}$, presumably because the interface layer did not significantly influence the volatility of this aroma.

As previously mentioned, full-fat cream is an oil-in-water emulsion containing anhydrous milk fat as the dispersed phase and the aqueous phase of milk as the continuous phase. For the three esters and hexanal, the nature of the continuous phase had little effect on the calculated air-fullfat cream partition coefficient. This meant that the retention of aromas observed in skim milk was masked by the presence of $30 \%$ lipids in the emulsion. On the other hand, the retention of $\mathrm{t}$-2-hexenal by milk proteins was still visible in the presence of $30 \%$ lipids, indicating a strong interaction.

Contradictory results have been reported in the literature on the effect of emulsification on the volatility of aroma compounds [20]. Emulsification had an impact on the volatility of dimethyl sulfide [18] and ethyl 
hexanoate [20], whereas no effect was observed for ethyl butanoate [20].

The simple model (Eq. (4)) applied to estimating the partition coefficient, neglecting the contribution of the interface to partition, fitted well with measured values for temperatures below $40{ }^{\circ} \mathrm{C}$. However, above this temperature, a discrepancy appeared between calculated and measured values. Further studies on the impact of aroma compounds on the emulsion structure and organisation (surface area, droplet size and structure of proteins at the interface...) are needed to fully understand the partition behaviour of various aroma compounds over emulsions formed by complex food components such as dairy proteins and milk fat.

\section{ACKNOWLEDGEMENT}

The funding of this work by the "Région des Pays de la Loire" within the framework of the VANAM program "Interfaces, Emulsions et Mousses Liquides" is gratefully acknowledged.

\section{REFERENCES}

[1] Alaiz M., Giron J., Modification of histidine residues in bovine serum albumin by reaction with (E)-2-octenal, J. Agric. Food Chem. 42 (1994) 2094-2098.

[2] Buttery R.G., Guadagni D.G., Ling L.C., Flavor compounds: Volatilities in vegetable oil and oil-water mixtures. Estimation of odor threshold, J. Agric. Food Chem. 21 (1973) 198-201.

[3] Buttery R.G., Ling L.C., Guadagni D.G., Volatilities of aldehydes, ketones, and esters in dilute water solution, J. Agric. Food Chem. 17 (1969) 385-389.

[4] Cayot N., Taisant C., Arvisenet G., Meunier J.M., Voilley A., Flavouring ratios and partition coefficients for isoamyl acetate in various starch-based food matrices, Sci. Aliments 20 (2000) 561-574.

[5] Charles M., Lambert S., Brondeur P., Courthaudon J.L., Guichard E., Influence of formulation and structure of an oil-in-water emulsion on flavor release, in: Roberts D.D., Taylor A.J. (Eds.), Flavor Release, Ameri- can Chemical Society, Washington DC, USA, 2000, pp. 342-354.

[6] CNIEL. L'économie laitière en chiffres, Paris, 2001.

[7] Dubois C., Sergent M., Voilley A., Flavoring of complex media: a model cheese example, in: McGorrin R.J., Leland J.V. (Eds.), Flavor-Food Interactions, American Chemical Society, Washington DC, USA, 1996, pp. 217-226.

[8] Dubois-Barbier C., Influence des caractéristiques physico-chimiques d'un fromage frais sur son aromatisation par des composés volatils de l'ail, Thèse de l'université de Bourgogne, ENSBANA, Dijon, France, 1994.

[9] Ducros M., Gruson J.F., Sannier H., Estimation des enthalpies de vaporisation des composés organiques liquides. Partie 1. Applications aux alcanes, cycloalcanes, alcènes, hydrocarbures benzéniques, alcools, alcanes thiols, chloro et bromoalcanes, nitriles, esters, acides et aldéhydes, Thermochim. Acta 36 (1980) 39-65.

[10] Ebeler S.E., Pangborn R.M., Jennings W.G., Influence of dispersion medium on aroma intensity and headspace concentration of menthone and isoamyl acetate, J. Agric. Food Chem. 36 (1988) 791-796.

[11] Fabre M., Aubry V., Guichard E., Comparison of different methods: static and dynamic headspace and solid-phase microextraction for the measurement of interactions between milk proteins and flavor compounds with an application to emulsions, J. Agric. Food Chem. 50 (2002) 1497-1501.

[12] Fisher N., Widder S., How proteins influence food flavor, Food Technol. 51 (1997) 68-70.

[13] Gremli H.A., Interaction of flavor compounds with soy protein, J. Amer. Oil Chem. Soc. 51 (1974) 95A-97A.

[14] Guichard E., Langourieux S., Interactions between $\beta$-lactoglobulin and flavour compounds, Food Chem. 71 (2000) 301-308.

[15] Haahr A.M., Bredie W.L.P., Stahnke L.H., Jensen B., Refsgaard H.H.F., Flavour release of aldehydes and diacetyl in oil/water systems, Food Chem. 71 (2000) 355-362.

[16] Hall G., Anderson J., Volatile fat oxidation products. II. Influence of temperature on volatility of saturated, mono- and diunsaturated aldehydes in liquid media, Lebensm. Wiss. Technol. 16 (1983) 362-366.

[17] Kinsella J.E., Flavor perception and binding, Inform 1 (1990) 215-226.

[18] Land D.G., Some factors influencing the perception of flavour-contributing substances in food, in: Land D.G., Nursten H.E. (Eds.), Progress in Flavour Research, Applied Science Pub., London, UK, 1978, pp. 53-66. 
[19] Landy P., Druaux C., Voilley A., Retention of aroma compounds by proteins in aqueous solution, Food Chem. 54 (1995) 387-392.

[20] Landy P., Courthaudon J.L., Dubois C., Voilley A., Effect of interface in model food emulsion on the volatility of aroma compounds, J. Agric. Food Chem. 44 (1996) 526-530.

[21] McClements D.J., Appearance and flavor, in: McClements D.J. (Ed.), Food emulsions. Principles, practice, and techniques, CRC Press, Boca Raton, USA, 1999, pp. 267-294.

[22] McNulty P.B., Karel M., Factors affecting flavour release and uptake in $\mathrm{O} / \mathrm{W}$ emulsions. I. Release and uptake models, J. Food Technol. 8 (1973) 309-318.

[23] Mills O.E., Solms J., Interaction of selected flavour compounds with whey proteins, Lebensm. Wiss. Technol. 17 (1984) 331-335.

[24] Philippe E., Seuvre A.M., Schippa M., Voilley A., Flavour compound behaviour as a function of temperature in a model emulsion, in: Le Quéré J.L., Etiévant P.X. (Eds.), Xth Weurman Symposium, Beaune, France, 25-28 June 2002, Tec et Doc Éditions, Paris, in press.

[25] Reiners J., Nicklaus S., Guichard E. Interactions between $\beta$-lactoglobulin and flavour compounds of different chemical classes. Impact of protein on the odour perception of vanillin and eugenol, Lait 80 (2000) 347-360.
[26] Seuvre A.M., Espinosa-Diaz M.A., Voilley A., Influence of food matrix structure on the retention of aroma compounds, J. Agric. Food Chem. 48 (2000) 4296-4300.

[27] Swaisgood H.E., Protein and amino acid composition of bovine milk, in: Jensen R.G (Ed.), Handbook of milk composition, Academic Press, San Diego, USA, 1995, pp. 464-468.

[28] Swaisgood H.E., Characteristics of milk, in Fennema O.R. (Ed.), Food chemistry, Marcel Dekker, New York, USA, 1996, pp. 841-878.

[29] Taylor A.J., Volatile flavor release from foods during eating, CRC, Crit. Rev. Food Sci. Nutr. 36 (1996) 765-784.

[30] Taylor A.J., Linforth R.S.T., Flavour release in the mouth, Trends Food Sci. Technol. 7 (1996) 444-448.

[31] Weast R.C., Astle M.J., Handbook of Chemistry and Physics, 61st edn., CRC Press, Boca Raton, USA, 1980.

[32] Zhou S., Decker E.A., Ability of amino acids, dipeptides, polyamines, and sulfhydryls to quench hexanal, a saturated aldehydic lipid oxidation product, J. Agric. Food Chem. 47 (1999) 1932-1936.

[33] Zhou S., Decker E.A., Ability of carnosine and other skeletal muscle components to quench unsaturated aldehydic lipid oxidation products, J. Agric. Food Chem. 47 (1999) 51-55. 